V. I. Timoshenko' , L. K. Patryliak' ${ }^{2}$ Y u. V. Knyshenko ${ }^{1}$, V. M. Durachenko ${ }^{3}$, A. S. Dolinkevych ${ }^{3}$

\title{
Use of a "green" propellant in low-thrust control jet engine systems
}

\author{
${ }^{1}$ Institute of Technical Mechanics \\ of the National Academy of Sciences of U kraine and the State Space Agency of U kraine \\ 15 Leshko-Popel St., Dnipro 49005, U kraine; e-mail:knyshenko@ukr.net \\ ${ }^{2}$ V. P. Kukhar Institute of Bioorganic Chemistry and Petrochemistry \\ of the National Academy of Sciences of U kraine \\ 1 M urmanska St., Kyiv 02094, U kraine; e-mail: kyivsmartdefence gmail.com \\ ${ }^{3} Y$ uzhnoye State D esign Office \\ 3 Kryvorizka St., Dnipro 49008, U kraine; e-mail:das@ukr.net
}

The aim of this work is to analyze the state of the art in the development and use of pollution-free ["green") propellants in low-thrust jet engines used as actuators of spacecraft stabilization and flight control systems and to adapt computational methods to the determination of "green"-propellant engine thrust characteristics. The monopropellant that is now widely used in the above-mentioned engines is hydrazine, whose decomposition produces a jet thrust due to the gaseous reaction products flowing out of a supersonic nozzle. Because of the high toxicity of hydrazine and the complex technology of hydrazine filling, it is important to search for its less toxic substitutes that would compare well with it in energy and mass characteristics. A promising line of this substitution is the use of ion liquids classed with "green" ones. The main components of these propellants are a water solution of an ion liquid and a fuel component. The exothermic thermocatalytic decomposition of a "green" propellant is combined with the combustion of its fuel component and increases the combustion chamber pressure due to the formation of gaseous products, which produces an engine thrust. It is well known that a "green" propellant itself and the products of its decomposition and combustion are far less toxic that hydrazine and the products of its decomposition, The paper presents data on foreign developments of "green" propellants of different types, which are under test in ground (bench) conditions and on a number of spacecraft. The key parameter that governs the efficiency of the jet propulsion system thrust characteristics is the performance of the decomposition and combustion products, which depends on their temperature and chemical composition. The use of equilibrium high-temperature process calculation methods for this purpose is too idealized and calls for experimental verification. Besides, a substantial contribution to the end effect is made by the design features of propellant feed and flow through a fine-dispersed catalyst layer aimed at maximizing the monopropellant-catalyst contact area. As a result, in addition to the computational determination of the thrust characteristics of a propulsion system under design, its experimental tryout is mandatory. The literature gives information on the performance data of "green"propellant propulsion systems for single engines. However, in spacecraft control engine systems their number may amount to 8-16; in addition, they operate in different regimes and may differ in thrust/throttling characteristics, which leads to unstable propellant feed to operating engines. To predict these processes, the paper suggests a mathematical model developed at the Institute of Technical Mechanics of the National Academy of Sciences of Ukraine and the State Space Agency of Ukraine and adapted to "green"-propellant engine systems. The model serves to calculate the operation of low-thrust jet engine systems and describes the propellant flow in propellant feed lines, propellant valves, and combustion chambers. To implement the model, use was made of the results of experimental studies on a prototype "green"-propellant engine developed at Yuzhnoye State Design Office. The analysis of the experimental results made it possible to refine the performance parameters of the monopropellant employed and obtain computational data that may be used in analyzing the operation of a single engine or an engine system on this propellant type in ground and flight conditions,

Keywords "green" rocket propellant, development state, propellant chemical thermodynamics, low-thrust jet engine, rocket propellant performance, mathematical model, experiment, calculation

1. Decker M. M., Klein N., Freedman E., Leveritt C. S., Wojciechowski J. Q. HAN-Based Liquid Gun Propellants: Physical Properties, BRL-TR-2864, 1987. $64 \mathrm{pp}$.

2. Jankovsky R. S. HAN-based monopropellant 64 ppt assessment for spacecraft. NASA TM 107287, (Also AIAA-96-2863), 32nd AIAA/ASME/ASEE Joint Propulsion Conference and Exhibit, Lake Nuena Vista, FL, July 1-3, 1996.

https://doi.org/10.2514/6.1996-2863 
3. Fukuchi B., Nagase S., Maruizumi H., Ayabe M. HAN/HM-based monopropellant thrusters. IHI Engineering Review. 2010. V. 43. No. 1. Pp. 22 28.

4. Larsson A., Wingborg N. Green propellants based on ammonium dinitramide (ADN). Advances in Spacecraft Technologies. J. Hall (Ed.). InTech, 2011. URL: http://www.intechopen.com/books/advances-in-spacecrafttechnologies/green-propellants-based-on-ammonium-dinitramide-adn- (last accessed on July 15, 2021). https://doi.org/10.5772/13640

5. Patent US 20080064913 Self-adjusting catalyst for propellent decomposition. Fortini A. J., Babcock J. R., Wright M. J. United States Air Force. Publication Date: March 13, 2008.

6. Oommen C., Rajaraman S., Chandru Arun R., Rajeev R. Catalytic decomposition of hydroxylammonium nitrate monopropellant. 2011 International Conference on Chemistry and Chemical Process IPCBEE V. 10. 2011. IACSIT Press, Singapore. Pp. 205 - 209.

7. Patent US 7137244 B2. Reactor for decomposition of ammonium dinitramide-based liquid monopropellants and process for the decomposition. Gronland T.- A., Westrberg B., Bergman G. et al. Svenska Rymdaktiebolaget. - Publication Date: October 21, 2006.

8. Hwang C. H., Baek S. W., Cho S. J. Experimental investigation of decomposition and evaporation characteristics of HAN-based monopropellants. Combustion and Flame. 2014. V. 161. Pp. 1109-1116. https://doi.org/10.1016/j.combustflame.2013.09.026

9. Negri M., Grund L. Replacement of hidrazine: Overwiew and first results of the H2020 Project Rheform, The 6th European Conference for Aeronautics And Space Sciences (EUCASS). 2015. URL:

https://www.researchgate.net/publication/312283589 (last accessed on June 7, 2021).

10. Masse R. K., Allen M., Driscoll, Spores R. A., Arringtot L. A., Schneider S. J., Vasek T. E. AF-M315 Propulsion System Advances \& Improvements. Published online 22 Jul 2016. URL: https//doi/org/10.2514/6.2016-4577. https://doi.org/10.2514/6.2016-4577

11. Marshall W., Cavender D., Maynard A., Zuttarelli P. State of the Art in Green Propulsion -2020. Distribution Stattement A: Approved for Public Release; Distribution is Unlimited. PA\#20361. . https://nps.edu>documents> Distribution_Statement ...(last asccessed on August 15, 2021).

12. Kondrikov B. N., Annikov V. E., Egortsev V. Yu., De Luka L. T. Combustion of hydroxylammonium nitrate. Fizika Goreniya I Vzryva. 2000. V. 36. No. 1. Pp. 149 - 160. (in Russian). 
13. Nesterenko A. N., Solodova S. V. Promising monopropellant thermocatalic engines. Vestnik RGU im. Kanta. Fiziko-Matematicheskiye Nauki. 2008. Iss. 4. Pp. 80 - 84. (in Russian).

14. Kartashov Yu. I., Spilioti M. N., Novikov I. I., Lvov O. N., Franchuk V. B., Pervushina K. V. New high-energy low-toxicity monopropellant based on hydroxylamine nitrate. Physical-Chemical Aspects of Limiting States and Structural Changes in Continua, Materials, and Engineering Systems. Iss. 2. Yu. V. Petrov (Ed.). Saint Petersburg: Politekhnika, 2018. Pp. 51-57. (in Russian). https://doi.org/10.25960/7325-1134-5.51

15. Ryzhkov V. V., Sulinov A. V. Low-thrust propulsion systems and rocket engines on different physical principles for small and very small spacecraft control systems. VESTNIK of Samara University. Aerospace and Mechanical Engineering. 2018. V. 176. No. 4. Pp. 115-128. (in Russian). https://doi.org/10.18287/2541-7533-2018-17-4-115-128

16. ASTRA 4 / rs Software Package. Version 1:07S. Simulation of Chemical and Phase Equilibria at High Temperatures: User's Manual. Moscow: Bauman Moscow State Technical University, 1991. 38 pp. (in Russian).

17. Timoshenko V. I., Knyshenko Yu. V., Koshkin M. I. Computational and experimental support of the development of low-thrust jet propulsion systems. Teh. Meh. 2005. No. 2. Pp. 50-64. (in Russian).

18. Timoshenko V. I., Knyshenko Yu. V., Durachenko V. M., Anishchenko V. M. Problems of development of controlling liquid jet system, which is powered from lines of a booster of the launch vehicle upper stage Kosm. Nauka Tehnol. 2016. V. 22. No. 1. Pp. 20-35. (in Russian).

https://doi.org/10.15407/knit2016.01.020

19. Timoshenko V. I., Knyshenko Yu. V. Influence of the gas saturation of a liquid on the peculiarities of unsteady flows in intricate pipelines. Journal of Engineering Physics and Thermophysics. 2018. V. 91. No. 6. Pp. 1434-1443. https://doi.org/10.1007/s10891-018-1878-9

20. Tymoshenko V. I., Knyshenko Yu. V., Durachenko V. M., Asmolovskyi S. $\mathrm{O}$. Analysis of the operation of the control jet engines of the Cyclone-4M launch vehicle upper stage at sustainer engine startups and shutdowns. Teh. Meh. 2020. No. 2. Pp. 22-35. (in Ukrainian).

https://doi.org/10.15407/itm2020.02.022

21. Belyaev N. M., Belik N. P., Uvarov E. I. Spacecraft Jet Control Systems. Moscow: Mashinostroyeniye, 1979. 232 pp. (in Russian).

Received on October 28, 2021, in final form on November 26, 2021 
